\title{
Comparative efficacy of non-sedating antihistamine updosing in patients with chronic urticaria
}

\author{
Mario Sánchez-Borges ${ }^{1 *}$, Ignacio Ansoteguii ${ }^{2}$, Jorge Montero Jimenez ${ }^{3}$, Maria Isabel Rojo ${ }^{4}$, Carlos Serrano ${ }^{5}$ \\ and Anahí Yañez ${ }^{6}$
}

Keywords: Angioedema, Antihistamines, Chronic urticaria

\section{Introduction}

Urticaria and angioedema lasting more than 6 weeks have been designated as chronic urticaria (CU). It encompasses two major subtypes: chronic spontaneous urticaria (CSU) (previously known as chronic idiopathic urticaria) (CIU) and chronic inducible urticaria. CSU has been defined as wheals and/or angioedema that are endogenous and independent of any external physical stimulus. It affects 0.5 to $1 \%$ of the population [1]. In 40 to $45 \%$ of patients with CSU autoantibodies to the high affinity IgE receptor (FceRI) or to IgE itself are thought to play a psathogenic role, whereas 55 to $60 \%$ of cases are considered idiopathic [2]. Inducible urticarias include all forms of physical urticarias (cold-induced, heat-induced, solar, and pressure urticaria).

According to the International Guidelines for the management of urticaria and angioedema non-sedating, second generation antihistamines (NSAHs) are recommended for the treatment of $\mathrm{CU}$ [3]. Nevertheless, a considerable proportion of patients do not respond sufficiently to NSAHs. According to Humphreys and Hunter up to $40 \%$ of patients with CU may not achieve good control with antihistaminic therapy [4]. They reported that out of $390 \mathrm{CU}$ patients who were treated with antihistamines $44 \%$ responded well, $29 \%$ became asymptomatic, and $15 \%$ showed partial improvement. In a recent paper from Japan it was observed that the improvement rates (defined as a urticaria symptom score UAS $\leq 3$ ) in 117 $\mathrm{CU}$ patients who received standard doses of AHs were

\footnotetext{
*Correspondence: sanchezbmario@gmail.com

${ }^{1}$ Allergy and Clinical Immunology Department, Centro Médico-Docente la, Trinidad and Clínica El Avila, 6a transversal Urb. Altamira, piso 8, consultorio 803, Caracas 1060, Venezuela

Full list of author information is available at the end of the article
}

$36.6 \%$ at 12 months, $51.2 \%$ at 24 months, and $66.1 \%$ at 60 months, while the remission rates were $11.5 \%, 13.9 \%$, and $27.7 \%$, respectively [5].

In patients that do not respond to standard doses, the next step in guideline-based therapy is to increase $\mathrm{AH}$ doses up to 4 times [3]. Investigations assessing the response to various NSAHs have demonstrated that up-dosing is significantly more effective in reducing symptoms of $\mathrm{CU}$ than standard-dose treatment [6]. According to Kaplan, high-dose antihistamines are effective in $45-60 \%$ of patients with CSU [7], while about one third are antihistamine resistant regardless of which dose is used $[8,9]$.

The present article is a review of the literature on the treatment of $\mathrm{CU}$ with increased doses of NSAHs in order to investigate if there are differences in efficacy between the various second generation AHs that have been studied in controlled protocols. It must be noticed, however, that it is difficult to find clinical investigations that strictly follow the criteria recommended by the guidelines on the management of urticaria, and therefore studies included in this review were those in which higher doses of NSAHs were used regardless of the clinical response to conventional doses.

AHs included in this review are desloratadine, levocetirizine, fexofenadine, and the recently introduced NSAHs rupatadine and bilastine. Bilastine belongs to the piperidine class of antihistamines as do loratadine, desloratadine, and fexofenadine. Like other antihistamines bilastine is an $\mathrm{H} 1$ receptor inverse agonist. In vitro studies have shown that bilastine has a high specific affinity for the H1-receptor but it has no or very low affinity for 30 other tested receptors. The affinity for the $\mathrm{H} 1$ receptor is 3 and 6 times higher 
Table 1 Studies included in this comparative analysis

\begin{tabular}{|c|c|c|c|c|c|c|c|c|}
\hline Author & Year & Drug & $\begin{array}{l}\text { Study } \\
\text { design }\end{array}$ & $\begin{array}{c}\text { Treatment } \\
\text { duration (days) }\end{array}$ & $\begin{array}{l}\text { Urticaria } \\
\text { subtype }\end{array}$ & $\mathrm{n}$ & $\begin{array}{l}\text { Parameter } \\
\text { of efficacy }\end{array}$ & $\begin{array}{r}\text { Reference } \\
\text { numbers }\end{array}$ \\
\hline Finn & 1999 & Fexofenadine & $\mathrm{DB}, \mathrm{PC}$ & 28 & CSU/CIU & 439 & MPS & 17 \\
\hline Nelson & 2000 & Fexofenadine & $\mathrm{R}, \mathrm{DB}, \mathrm{PC}$ & 28 & CSU/CIU & 418 & MPS & 18 \\
\hline Giménez-Arnau & 2007 & Rupatadine & $\mathrm{R}, \mathrm{DB}, \mathrm{PC}$ & 28 & $\mathrm{CSU} / \mathrm{CIU}$ & 329 & MPS & 19 \\
\hline Dubertret & 2007 & Rupatadine & $\mathrm{R}, \mathrm{DB}, \mathrm{PC}$ & 28 & $\mathrm{CSU} / \mathrm{CIU}$ & 277 & MPS & 20 \\
\hline Siebenhaar & 2009 & Desloratadine & $\mathrm{R}, \mathrm{DB}, \mathrm{PC}$ & 7 & $\mathrm{ACU}$ & 30 & $\%$ SF & 21 \\
\hline Staevska & 2010 & Desloratadine & $\mathrm{DB}, \mathrm{PC}$ & 28 & CSU/CIU & 40 & $\%$ SF & 22 \\
\hline Staevska & 2010 & Levocetirizine & $\mathrm{DB}, \mathrm{PC}$ & 28 & CSU/CIU & 40 & $\% \mathrm{SF}$ & 22 \\
\hline Krause & 2013 & Bilastine & $\mathrm{R}, \mathrm{DB}, \mathrm{PC}$ & 7 & $A C U$ & 20 & $\% \mathrm{SF}$ & 23 \\
\hline
\end{tabular}

$D B$ double-blind, $P C$ placebo-controlled, $R$ randomized.

CSU chronic spontaneous urticaria, CIU chronic idiopathic urticaria, ACU acquired cold urticaria

MPS mean pruritus score, $\%$ SF percentage of symptom-free patients.

than for cetirizine and fexofenadine, respectively $[10,11]$. Rupatadine fumarate is a new potent, long acting, orally active dual antagonist of both histamine $\mathrm{H} 1$ and PlateletActivating Factor (PAF) receptors. In in vivo and in vitro studies rupatadine was as potent or even more potent than other second generation antihistamines (loratadine, terfenadine and cetirizine) or selective PAF antagonists [12].

\section{Methods}

A literature search of PubMed/MEDLINE looking specifically at the studies that investigated the effects of increased doses of NSAHs in patients with all subtypes of $\mathrm{CU}$ was conducted. For analysis of the efficacy, only double-blind, placebo-controlled studies were selected, whereas uncontrolled studies were excluded.

Data on study drug, doses, study design, treatment duration, subtype of urticaria being treated, number of patients, and main parameter of efficacy, were collected. When available, efficacy data were pooled from different studies that utilized the same drug dose. The proportions of patients responding to the therapy were compared using the Fisher's exact test with a significance level of $\mathrm{p}<0.05$.

\section{Results}

Twelve studies that investigated the effects of higher doses of NSAHs were identified in this search. Among those, 3 papers dealing with the treatment of patients with CSU were excluded from analysis because of their open design, 2 employing cetirizine and one that utilized ebastine [13-15]. Another study by Metz et alwas also excluded because it assessed exclusively the effects of a $20 \mathrm{mg}$ dose of rupatadine in patients with acquired cold urticaria whereas no comparisons with other doses of the drug were done [16].

Table 1 summarizes the details from 8 double-blind, placebo-controlled studies included in this report. Two investigations used fexofenadine, rupatadine, or desloratadine, and one study was done with levocetirizine or bilastine. In most studies NSAHs were administered for 28 days, although in the papers by Siebenhaar (with desloratadine) and Krause (with bilastine) the drugs were given for 7 days. Six articles included patients with CSU/CIU and other 2 studied patients with acquired cold urticaria. Four investigations chose mean pruritus scores as the main outcome, and the other 4 utilized the percentage of symptom-free patients as the main parameter of efficacy.

Table 2 presents the results of the 8 studies in regard to efficacy of the treatment. It can be observed that the proportion of symptom improvement was highly variable, ranging from $3.4 \%$ to $71.6 \%$, depending on the drug and dose. The best responses were obtained with fexofenadine, rupatadine, and bilastine.

The statistical comparison of the data is shown in Figure 1. There were not significant differences in efficacy between fexofenadine and bilastine, rupatadine and

Table 2 Efficacy of increased doses of non-sedating antihistamines in patients with chronic urticaria

\begin{tabular}{lcccc}
\hline & & & \multicolumn{2}{c}{ Efficacy } \\
\cline { 4 - 5 } Author ${ }^{\text {ref }}$ & Drug & Dose (mg) & Responders/n & $\%$ \\
\hline Finn [17] & Fexofenadine & 120 BD & $46 / 89$ & 51.6 \\
Finn [17] & Fexofenadine & 240 BD & $54 / 83$ & 64.9 \\
Nelson [18] & Fexofenadine & 120 BD & $33 / 77$ & 42.8 \\
Nelson [18] & Fexofenadine & 240 BD & $46 / 82$ & 56.0 \\
Giménez-Arnau [19] & Rupatadine & 20 QD & $69 / 109$ & 63.3 \\
Dubertret [20] & Rupatadine & 20 QD & $48 / 67$ & 71.6 \\
Siebenhaar [21] & Desloratadine & 20 QD & $15 / 30$ & 50.0 \\
Staevska [22] & Desloratadine & 10 QD & $7 / 36$ & 19.4 \\
Staevska [22] & Desloratadine & 20 QD & $1 / 29$ & 3.4 \\
Staevska [22] & Levocetirizine & 10 QD & $8 / 31$ & 25.8 \\
Staevska [22] & Levocetirizine & 20 QD & $5 / 23$ & 21.7 \\
Krause [23] & Bilastine & 40 QD & $11 / 20$ & 55.0 \\
Krause [23] & Bilastine & 80 QD & $12 / 20$ & 60.0 \\
\hline
\end{tabular}



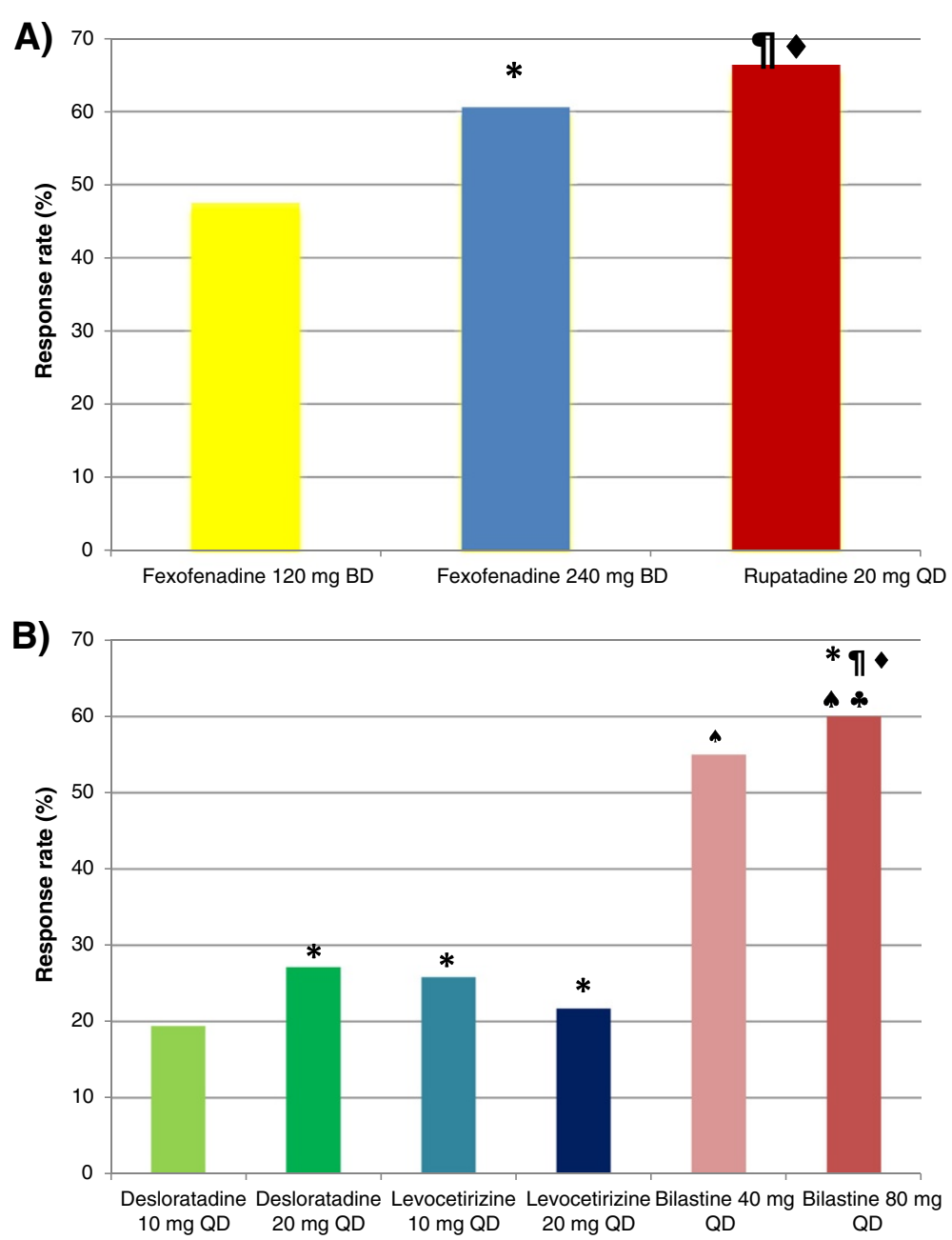

Figure 1 Efficacy of increased doses of nonsedating antihistamines in patients with chronic urticaria. A) According to mean pruritus score (MPS). *Fexofenadine $120 \mathrm{mg}$ vs Fexofenadine $240 \mathrm{mg} \mathrm{p}=0.01$, 9 Fexofenadine $120 \mathrm{mg}$ vs Rupatadine $20 \mathrm{mg} p=0.0001$, Fexofenadine $240 \mathrm{mg}$ vs Rupatadine $20 \mathrm{mg} \mathrm{p}=0.03$. B) According to percentage of symptom-free patients. * Desloratadine $10 \mathrm{mg}$ vs Desloratadine $120 \mathrm{mg}$, Desloratadine $10 \mathrm{mg}$ vs Levocetirizine $10 \mathrm{mg}$, Desloratadine $10 \mathrm{mg}$ vs Levocetirizine 20 mg, Desloratadine $20 \mathrm{mg}$ vs Levocetirizine $10 \mathrm{mg}$, Desloratadine $20 \mathrm{mg}$ vs Levocetirizine 20 mg, Levocetirizine $10 \mathrm{mg}$ vs Levocetirizine 20 mg, Bilastine $40 \mathrm{mg}$ vs Bilastine $80 \mathrm{mg}$ p n.s. ๆ Desloratadine 10 mg vs Bilastine $40 \mathrm{mg} \mathrm{p}=0.006$. Desloratadine $10 \mathrm{mg}$ vs Bilastine $80 \mathrm{mg} \mathrm{p}=0.002$. Desloratadine $20 \mathrm{mg}$ vs Bilastine $40 \mathrm{mg}$, Desloratadine $20 \mathrm{mg}$ vs Bilastine $80 \mathrm{mg}$, Levocetirizine $10 \mathrm{mg}$ vs Bilastine $40 \mathrm{mg} p=0.02$. Levocetirizine $10 \mathrm{mg}$ vs Bilastine $80 \mathrm{mg} p=0.01$.

bilastine, and desloratadine and levocetirizine. However, fexofenadine, rupatadine, and bilastine showed significantly higher efficacy than desloratadine or levocetirizine, and rupatadine had higher efficacy than fexofenadine.

\section{Discussion}

According to current recommendations, patients with $\mathrm{CU}$ who do not respond to licensed doses of NSAHs should be switched to higher doses in order to obtain a better disease control. A number of publications that evaluated different NSAHs in increasing doses have clearly demonstrated that a higher proportion of patients previously uncontrolled exhibit significant improvements of their symptoms after going through this approach [6]. It is important to mention that these enhanced results have generally been accomplished without compromising patient's safety, since no increased rates of side effects, including somnolence, have been observed.

The mechanisms explaining patient's benefits from up-dosing are not completely understood, but increased in vivo receptor occupancy [24,25], and effects of antihistamines on additional receptors have been proposed [26]. Observed differences in response to different NSAHs cannot be explained by terminal elimination half-life, duration of action, higher tissue/plasma concentration ratios or the presence of active metabolites in the skin [27]. An alternative hypothesis would be a differential H1-receptor occupancy by free (unbound) H1 antihistamine $[25,28]$. The results discussed in present paper are in agreement with a previous report by Church and 
Maurer [29] who proposed that although the Ki may be an indicator of anti-H1 antihistamine potency in vitro, the large differences in volume of distribution and tissue accumulation in humans preclude this from being a good predictor of clinical efficacy in CSU.

In a previous review article we had proposed that favorable responses to high doses of NSAHs in patients with CU were not uniformly observed, and it was likely that there would be dissimilar results when outcomes from different studies were compared [6]. Present article shows that in fact some higher doses of NSAHs, notably fexofenadine, rupatadine, and bilastine, induced better objective improvements than desloratadine and levocetirizine (Table 2, Figure 1). The reasons for these differences are not clear at this time, but may depend on differential properties of the drugs, such as their chemical structure, in vivo anti-inflammatory actions, metabolism, blockade of various receptors, and interactions with transporter systems (e.g., P-glycoprotein) [30]. In the case of fexofenadine, however, two studies demonstrated that higher doses were not more efficacious than the standard $60 \mathrm{mg}$ twice a day dose $[17,18]$.

Since more than $30 \%$ of CU patients are refractory to antihistamine therapy, additional pharmacological strategies are available. Alternative drugs inducing better responses in $\mathrm{AH}$-resistant $\mathrm{CU}$, as based on scientific evidences, include the addition of leukotriene receptor antagonists, corticosteroids, cyclosporine, or omalizumab $[7,31,32]$. The choice of alternative, off-label agents, should be based on availability, relative safety, and socioeconomic considerations.

When administering high doses of antihistamines questions on their safety are usually put forward. Studies conducted up to now have not demonstrated important concerns on predictable or newer adverse effects of up to 4 times recommended doses of NSAHs. Headache was the most frequent adverse effect reported for fexofenadine [17] and rupatadine [19], but its incidence was not higher than in placebo-treated patients. Somnolence, drowsiness, or sedation was uncommon, although for patients treated with rupatadine $20 \mathrm{mg}$ somnolence was observed more often than in the placebo group in two studies $[19,20]$. The utilization of increased doses of desloratadine, levocetirizine, and bilastine has not been associated with adverse effects. Additionally, Staevska et al reported that patients taking higher doses of levocetirizine or desloratadine showed a paradoxical decrease in somnolence that was attributed to the relief from urticaria-related discomfort leading to a better quality of sleep although an alternative explanation would be the development of tolerance to the central nervous sedative effects of the antihistamines [22].

The results presented in this paper must be taken into consideration cautiously because there is a large heterogeneity between studies included in regard to various aspects of the investigation such as the subtype of chronic urticaria under study, duration of the treatment, study design, drug doses, and primary outcomes.

We can conclude that increased doses of NSAHs show an improved efficacy in patients with $\mathrm{CU}$ who do not respond to approved doses. According to the studies presented in this paper, this conclusion would be applicable to CSU/CIU and acquired cold urticaria, but more research would be necessary to be able to elucidate if this approach is valid for other types of urticaria. There are differences in efficacy of these drugs that should be taken into account in the clinical setting. The use of double approved doses of fexofenadine, rupatadine, or bilastine shows an objective improvement in most $(>50 \%)$ of patients that respond to antihistamines. Desloratadine requires four times the approved dose to reach similar results.

There is still the need for additional studies designed to investigate the response to high doses of NSAHs in patients who do not respond to recommended doses, adapted to current guideline recommendations.

\section{Competing interests}

MSB, IA, JMJ, MIR, CS and AY have been advisors for FAES Farma, Sanofi, Menarini and Pfizer.

\section{Authors' contributions}

All authors contributed equally in drafting the manuscript. All authors read and approved the final manuscript.

\section{Author details}

${ }^{1}$ Allergy and Clinical Immunology Department, Centro Médico-Docente la, Trinidad and Clínica El Avila, 6a transversal Urb. Altamira, piso 8, consultorio 803, Caracas 1060, Venezuela. ${ }^{2}$ Department of Allergy and Immunology, Hospital Quirón Bizkaia, Erandio, Spain. ${ }^{3}$ Unidad de Alergia, Hospital Mexico, CCSS, San Jose, Costa Rica. ${ }^{4}$ Allergy, Juarez Hospital, Mexico City, Mexico. ${ }^{5}$ Allergy Unit, Hospital Fundación Valle del Lili, Cali, Colombia.

${ }^{6}$ Investigaciones en Alergia y Enfermedades Respiratorias, InAER, Buenos Aires, Argentina.

Received: 20 June 2014 Accepted: 30 September 2014 Published: 26 November 2014

\section{References}

1. Maurer M, Weller K, Bindslev-Jensen C, Giménez-Arnau A, Bousquet PJ, Bousquet J, Canonica GW, Church MK, Godse KV, Grattan CE, Greaves MW, Hide M, Kalogeromitros D, Kaplan AP, Saini SS, Zhu XJ, Zuberbier Y: Unmet needs in chronic spontaneous urticaria. A GA ${ }^{2}$ LEN task force report. Allergy 2011, 66:317-330.

2. Kaplan AP, Greaves M: Pathogenesis of chronic urticaria. Allergy 2009, 39:777-787.

3. Zuberbier T, Aberer W, Asero R, Bindslev-Jensen C, Brzoza Z, Canonica GW, Church MK, Ensina LF, Giménez-Arnau A, Godse K, Gonçalo M, Grattan C, Hebert J, Hide M, Kaplan A, Kapp A, Abdul Latiff H, Mathelier Fusade P, Metz M, Nast A, Saini SS, Sánchez-Borges M, Schmid-Grendelmeier P, Simons FER, Staubach P, Sussman G, Toubi E, Vena GA, Wedi B, Zhu XJ, Maurer M: The EAACI/GA(2)LEN/EDF/WAO guidelinefor the definition, classification, diagnosis and management of urticarial: the 2013 revision and update. Allergy 2014, 69:868-887.

4. Humphreys F, Hunter JA: The characteristics of urticaria in $\mathbf{3 9 0}$ patients. Br J Dermatol 1998, 138:635-638. 
5. Hiragun M, Hiragun T, Mihara S, Akita T, Tanaka J, Hide M: Prognosis of chronic spontaneous urticaria in 117 patients not controlled by a standard dose of antihistamine. Allergy 2013, 68:229-235.

6. Sánchez-Borges M, Caballero-Fonseca F, Capriles-Hulett A: Treatment of recalcitrant chronic urticaria with nonsedating antihistamines: is there evidence for updosing? I Investig Allergol Clin Immunol 2013, 23:141-144.

7. Kaplan AP: Treatment of chronic spontaneous urticaria. Allergy Asthma Immunol Res 2012, 4:326-331.

8. Zuberbier T, Balke M, Worm M, Edenharter G, Maurer M: Epidemiology of urticaria: a representative cross-sectional population survey. Clin Exp Dermatol 2010, 35:869-873.

9. Giménez-Arnau A, Izquierdo I, Maurer M: The use of a responder analysis to identify clinically meaningful differences in chronic urticaria patients following placebo-controlled treatment with rupatadine 10 and $20 \mathrm{mg}$. J Eur Acad Dermatol Venereol 2009, 23:1088-1091.

10. Corcostegui R, Labeaga L, Berisa A, Orjales A: Preclinical pharmacology of bilastine, a new selective histamine $\mathrm{H} 1$ receptor antagonist: receptor selectivity and in vitro antihistaminic activity. Drugs in R and D 2005, 6:371-384.

11. Simons FER, Simons KJ: Histamine and $\mathrm{H} 1$-antihistamines: celebrating a century of progress. J Allergy Clin Immunol 2011, 128:1130-1150.

12. Merlos M, Giral M, Balsa D, Ferrando R, Queralt M, Puigdemont A, Garcia-Rafanell J, ForN J: Rupatadine, a new potent, orally active dual antagonist of histamine and platelet-activating factor (PAF). J Pharmacol Exp Ther 1997, 280:114-121.

13. Kameyoshi Y, Tanaka T, Mihara S, Takahagi S, Niimi N, Hide M: Increasing the dose of cetirizine may lead to better control of chronic idiopathic urticaria: an open study of 21 patients. Br J Dermatol 2007, 157:803-804.

14. Asero R: Chronic unremitting urticaria: is the use of antihistamines above the licensed dose effective? A preliminary study of cetirizine at licensed and above-licensed doses. Clin Exp Dermatol 2006, 32:34-38.

15. Godse KV: Ebastine in chronic spontaneous urticarial in higher doses. Indian J Dermatol 2011, 56:597-598

16. Metz M, Scholtz E, Ferran M, Izquierdo I, Giménez-Arnau A, Maurer M: Rupatadine and its effects on symptom control, stimulation time, and temperature tresholds in patients with acquired cold urticaria. Ann Allergy Asthma Immunol 2010, 104:86-92.

17. Finn AF, Kaplan AP, Fretwell R, Qu R, Long J: A double-blind, placebo-controlled trial of fexofenadine $\mathrm{HCl}$ in the treatment of chronic idiopathic urticarial. J Allergy Clin Immunol 1999, 103:1071-1078.

18. Nelson HS, Reynolds R, Mason J: Fexofenadine $\mathrm{HCl}$ is safe and effective for treatment of chronic idiopathic urticaria. Ann Allergy Asthma Immunol 2000, 84:517-522.

19. Giménez-Arnau A, Pujol RM, lanosi S, Kaszuba A, Malbran A, Poop G, Donado E, Perez I, Izquierdo I, Arnaiz E, the Rupatadine Urticaria Study Group: Rupatadine in the treatment of chronic idiopathic urticaria: a double-blind, randomized, placebo-controlled multicenter study. Allergy 2007, 62:539-546.

20. Dubertret L, Zalupca L, Cristodoulo T, Benea V, Medina I, Fantin S, Lahfa M, Pérez I, Izquierdo I, Arnaiz E: Once-daily rupatadine improves the symptoms of chronic idiopathic urticaria: a randomized, double-blind, placebo-controlled study. Eur J Dermatol 2007, 17:223-228.

21. Siebenhaar F, Degener F, Zuberbier T, Martus P, Maurer M: High-dose desloratadine decreases wheal volume and improves cold provocation tresholds compared with standard-dose treatment in patients with acquired cold urticaria: a randomized, placebo-controlled, crossover study. J Allergy Clin Immunol 2009, 123:672-679.

22. Staevska M, Popov T, Kralimarkova T, Lazarova C, Kraeva S, Popova D, Church DS, Dimitrov V, Church MK: The effectiveness of levocetirizine and desloratadine in up to 4 times conventional doses in difficult-to-treat urticaria. J Allergy Clin Immunol 2010, 125:676-682.

23. Krause K, Spohr A, Zuberbier T, Church MK, Maurer M: Up-dosing with bilastine results in improved effectiveness in cold contact urticaria. Allergy 2013, 68:921-928.

24. Gillard M, Benedetti MS, Chatelain P, Baltes E: Histamine H1 receptor occupancy and pharmacodynamics of second generation h1-antihistamines. Inflamm Res 2005, 54:367-369.

25. Simons KJ, Benedetti MS, Simons FE, Gillard M, Baltes E: Relevance of $\mathrm{H} 1$-receptor occupancy to $\mathrm{H} 1$-antihistamine dosing in children. J Allergy Clin Immunol 2007, 119:1551-1554.
26. Queralt M, Merlos $M$, Giral M, Puigdemont A: Dual effect of a new compound, rupatadine, on edema induced by platelet-activating factor and histamine in dogs: comparison with antihistamines and PAF-antagonists. Drug Dev Res 1996, 39:12-18.

27. Simons FER, Akdis CA: Histamine and Antihistamines. In Middleton's Allergy. Principlesa and Practice. Chapter 94th edition. Edited by Adkinson NF, Bochner BS, Burks AW, Busse WW, Holgate ST, Lemanske RF, O'Hehir RE. Philadelphia: Elsevier Saunders; 2014:1503-1533.

28. Gillman S, Gillard M, Strolin BM: The concept of receptor-occupancy to predict clinical efficacy: a comparison of second-generation $\mathrm{H} 1$ antihistamines. Allergy Asthma Proc 2009, 30:366-376.

29. Church MK, Maurer $\mathrm{M}: \mathrm{H}(1)$-antihistamines and urticaria: how can we predict the best drug for our patient? Clin Exp Allergy 2012, 42:1423-1429.

30. Bailey DG: Fruit juice inhibition of uptake transport: a new type of food-drug interaction. Br J Clin Pharmacol 2010, 70:645-655.

31. Sánchez-Borges M, Asero R, Ansotegui IJ, Baiardini I, Bernstein JA, Canonica GW, Gower R, Kahn DA, Kaplan AP, Katelaris C, Maurer M, Park HS, Potter P, Saini S, Tassinari P, Tedeschi A, Ye YM, Zuberbier T, WAO Scientific and Clinical Issues Council: Diagnosis and treatment of urticaria and angioedema: a worldwide perspective. World Allergy Organ J 2012, 5:125-147.

32. Khan DA: Alternative agents in refractory chronic urticaria: evidence and considerations on their selection and use. J Allergy Clin Immunol In Practice 2013, 1:433-440.

doi:10.1186/1939-4551-7-33

Cite this article as: Sánchez-Borges et al:: Comparative efficacy of non-sedating antihistamine updosing in patients with chronic urticaria. World Allergy Organization Journal 2014 7:33.

\section{Submit your next manuscript to BioMed Central and take full advantage of:}

- Convenient online submission

- Thorough peer review

- No space constraints or color figure charges

- Immediate publication on acceptance

- Inclusion in PubMed, CAS, Scopus and Google Scholar

- Research which is freely available for redistribution 